neurofibromatosis and leukaemia are uncommon conditions and the above three cases suggest that there may be a link between them. It may well be merely coincidence that all three patients are males.We are, etc.,

W. R. MCWHIRTER D. C. L. SAVAGE B. M. WIILIAMS

Maryfield Hospital,

Dundee 1 Hardisty, R. M., Speed, D. E., and Till, M.,

\section{Pupillary Paralysis after Tranquillizer}

SIR,-Though I accept Dr. R. Pearson's criticism (11 September, p. 639) that the evidence in my letter (28 August, p. 530) is not proof that pimozide caused the side effects mentioned, there are two aspects of this subject on which I would like to comment.

First, it is common experience with high doses of the phenothiazine and butyrophenone groups of drugs that blurring of vision along with other side effects occurs, and that pupillary dilation and sluggish light reactions are observed concomitantly. Administration of antiparkinsonian agents often alleviates the condition, though the dose of antipsychotic drug usually has to be reduced before this side effect is removed. There is often a wide gap between the theoretical effects predicted by known pharmacology of drugs (often inferred only from animal experiments), and what is clinically observed. I would put forward the proposition that while one would expect anticholinergic agents such as benztropine and orphenadrine to cause pupillary dilation, the clinical observation remains that blurring of vision is diminished by these drugs in the complicated iatrogenic state of affairs introduced by the administration of antipsychotic agents.

My second point is that pimozide is suggested by the manufacturers (Janssen Pharmaceuticals) to have a very low incidence of side effects-and yet the case under discussion showed all the usual complications.-I am, etc.,

Royal El:nburgh Hospital,

R. J. M. CRawford

Edinburgh

\section{Survival in Severe Congenital Heart Disease}

SIR,-Your recent correspondents (4 September, p. 579, and 18 September, p. 701) have illustrated some of the problems facing all those trying to provide services for infants and children with cardiac lesions. Of course the situation imagined by Dr. E. T. O. Slater (18 September, p. 702) infrequently arises in such a clear cut manner. More often the problem is that of an infant who clearly must have an operation very early or die, and one therefore defers an older child who is in a less pressing situation. If this is done on a sufficient number of occasions it will eventually turn out that one has guessed wrong, and an older child will suffer, perhaps irremediably. One is weighing the life of one older child against those of several infants, an equation perhaps less simply solved than Dr. Slater's.

Similar problems arise at the diagnostic stage. Cardiac investigations have to be rationed, and one does this partly by not investigating some of those who clearly can afford to wait, in the hope that some day it will be possible to deal with them; and partly by denying investigation to those small infants who seem likely to be unsaveable. Again one cannot always be right, but to detect each of those infants with a reasonable chance of a long and happy life after operation would also mean investigating several who turn out to be incurable. Even with such rationing many treatable infants are imperilled by unavoidable delay. The marginal cost of saving more ill infants than at present is high, but this should be faced.

Other difficulties face administrators. Apart altogether from the fact that poor facilities are unlikely to attract good applicants for posts, both equipment and staff are expensive and it is uneconomic to supply one without the other. Another problem concerns the relationship with other services. Paediatric cardiac services should certainly be linked in some way with a nearby adult service, but operations are being done progressively earlier in life and the problems are increasingly those of the small infant. There seems, therefore, increasing reason to associate this work preferentially with those other services, such as neonatal surgery, which require similar expertise-particularly that of paediatric anaesthesia.

Not all administrations are able to solve these problems, and because of the expense I wonder if it is not time for some help and guidance for them from the Department of Health.-I am, etc.,

Royal Manchester Children's Hospital,
Pendlebury, near Manchester

\section{Nephrotoxicity of Cephaloridine}

SIR,-Dr. R. Gabriel and others (31 October, 1970 , p. 283) reported reversible acute renal failure after cephaloridine. We recently encountered a case of fatal acute renal failure following cephaloridine administration and thought that this complication of the drug deserves documentation.

The patient was a 70-year-old woman with a complex mitral valve defect. She was febrile and very ill. Streptococcus viridans was cultured from her blood. Though the patient was known to be sensitive to penicillin a therapeutic trial with ampicillin was attempted. This resulted in a widespread rash, and cephaloridine was therefore substituted. During the course of this treatment progressive oliguria was noted. Blood urea rose from $38 \mathrm{mg} / 100 \mathrm{ml}$ to $200 \mathrm{mg} / 100 \mathrm{ml}$ and creatinine reached $5 \mathrm{mg} / 100 \mathrm{ml}$. Though peritoneal dialysis brought about an improvement in serum biochemistry, the patient's general condition continued to deteriorate and she died. Necropsy was refused, but a percutaneous renal biopsy was performed within one hour after death.

All the glomeruli were intact. Many tubules were without their epithelial lining. The tubular lumina contained amorphous eosinophilic material which was in some cases granular. There were patches of tubular atrophy with interstitial oedema and lymphocytic and eosinophilic infiltration. The acute renal failure could have been determined by severai causes. Subacute bacterial endocarditis may produce renal damage. However, it does not usually produce acute renal failure. Ampicillin is a fairly innocuous drug so far as the kidneys are concerned, and in any event, it had been given for one day only, while cephaloridine was given for a whole month.

Our patient was known to be sensitive to penicillin, and cross sensitivity between penicillin and cephaloridine has already been described. ${ }^{1}$ The clinical manifestation of sensitivity ranges widely from mild urticaria to severe renal damage and anaphylactic shock. There have been numerous reports on the aspects of nephrotoxicity of cephaloridine.2-5 These range from mild damage manifested by casts and albuminuria to the severe damage of acute renal failure. This drug has caused necrotic changes in the proximal tubules in experiments on animals, and these changes include hydropic swelling with fragmentation of the tubular cells. ${ }^{6}$

We conclude as others before us that cephaloridine should be used cautiously. Repeated estimation of the renal function must be performed and the dose should be related to the level of renal function.-We are, etc.,

Talma Rosenthal

Department of Internal Medicine,

Hayim BoIchis

Nephrology Section,

Tel Aviv University Hospital,

Ramat Gan, Israel

Scholand, J. F., Tennenbaum, J. I., and Cerelli, G. J., Fournal of the

2 Hinman, A. R., and Wolinsky, E., fournal of the American Medical Association, $1967,200,724$,
Galbraith, H. J. B., British fournal of Clinical Practice, 1967, 21, 331.

4 Seftel, H. C., Postgraduate Medical fournal, 1967, 43 suppl. 137.

5 Thomas, $B$. L., New England fournal of Medicine, 1969, 280, 505

- Perkins, R. L., Apicella, M. A., Lee, I. S., Cuppage, F. E., and Saslaw, S., Fournal of

\section{Diverticular Disease of the Colon}

SIR,-We were interested to read Dr. J. F. Calder's account (12 June, p. 654) of a single case of diverticular disease of the colon in a 40-year-old Bantu female resident in Zomba, Malawi. We have recently seen a Rhodesian African female patient with this condition. This would appear to be the only reported case of diverticular disease of the colon in an African resident in Rhodesia The patient, a 42-year-old female, underwent cholecystectomy for cholelithiasis. Multiple diverticula of the descending colon and sigmoid colon were noted at laparotomy and confirmed later with barium studies.

It is important to record the rarity of a disease in a region where its incidence is much lower than that seen elsewhere. If the disease should show an increase in incidence during subsequent years, the study of features related to the change in environment of this group of people may help elucidate the cause of the particular disease.We are, etc.

SIMON WAPNICK

University College of Rhodesia,

LESLIE LEVIN

Harari Central Hospital

\section{An XYY Individual of Average Feight}

SIR,-In reply to Dr. Dora Black's criticism (25 September, p. 768) we would like to make the following points:

(1) We reported the finding of an XYY 